\section{Chitosan Treatment Affects Plant Growth and Flower Quality in Eustoma grandiflorum}

\author{
K. Ohta, A. Taniguchi, N. Konishi, and T. Hosoki \\ Department of Agriculture, Shimane University, Matsue, Shimane 690-8504, \\ Japan
}

Additional index words. poly-( $1 \rightarrow 4)-\beta$-D-glucoseamine, Lisianthus, seedling quality, flower quality

\begin{abstract}
The effects of chitosan treatment on plant growth and flower quality of Eustoma grandiflorum (Raf.) Shinn. were investigated. The application of a soil mix of chitosan (1\%, w/w) at sowing time remarkably enhanced growth, whereas coating seed with $0.1 \%$ chitosan in lactate was ineffective. Plants grown in the chitosan-treated soil flowered 15 days earlier than did control plants, and the number and weight of cut flowers produced were greater than for control plants or plants from chitosan-treated seed. Chemical name used: poly-( $1 \rightarrow 4)-\beta-D$-glucoseamine (chitosan).
\end{abstract}

The growth of Eustoma grandiflorum seedlings is very slow, requiring 50 to $140 \mathrm{~d}$ from germination to transplanting (Harbaugh, 1995; Matsuo and Shirasaki, 1990; Tsukada et al., 1991a, 1991b). Acceleration of seedling growth would greatly improve cut-flower production in Eustoma grandiflorum. However, temperatures between 10 and $20^{\circ} \mathrm{C}$ during the seedling stage proved ineffective for growth promotion (Tsukada et al., 1982).

Chitosan, obtained by deacetylation of chitin, promotes shoot and root growth in Daikon radish (Raphanus sativus L.) (Tsugita et al., 1993), and hastens flowering time and increases flower number in passionfruit (Passiflora edulis Sims) (Utsunomiya and Kinai, 1994). Chitosan promotes growth of cabbage (Brassica oleracea L. var. capitata L.) callus in vitro (Hirano, 1988), and chitinoligosaccharide increases the chitinase activ-

Received for publication 19 Dec. 1997. Accepted for publication 16 Oct. 1998. The cost of publishing this paper was defrayed in part by the payment of page charges. Under postal regulations, this paper therefore must be hereby marked advertisement solely to indicate this fact. ity of rice (Shibuya et al., 1996). The objective of this study was to determine the influence of Eustoma grandiflorum and to examine the feasibility of using the chemical poly- $(1 \rightarrow 4)$ $\beta$-D-glucoseamine for cut-flower production.

\section{Materials and Methods}

Seeds of E. grandiflorum 'Kairyou Wakamurasaki' were soaked for $1 \mathrm{~h}$ in $0.1 \%$ chitosan (Sigma, St. Louis) dissolved in $0.25 \%$ lactic acid, and then air-dried. The chitosan had been previously ground to a fine powder in an electrical mill. Both seeds coated with $0.25 \%$ lactic acid alone and nontreated seeds were used as controls. For the soil treatment, $1.0 \%$ chitosan (by weight) was mixed with a sandy loam soil contained in 72-hole polystyrene foam trays. About 10 seeds were used in each cell (32-mm diameter, $50 \mathrm{~mm}$ deep), and three trays were used for each treatment. The trays were placed at $25^{\circ} \mathrm{C}$ day $/ 18^{\circ} \mathrm{C}$ night in natural daylight in a greenhouse. Starting 2 weeks after germination, the seedlings were watered daily and fertilized weekly with 300 $\mathrm{mg} \cdot \mathrm{L}^{-1} \mathrm{~N}$, using $15 \mathrm{~N}-8 \mathrm{P}-17 \mathrm{~K}$ water-soluble fertilizer. The seedlings were thinned to two per cell at the two-pair leaf stage. chitosan on seedling growth and flowering in
At 8 and 11 weeks after sowing, leaf length and width, and fresh and dry weights of the shoots and roots of 12 plants per treatment were determined. All treatments were replicated five times (15 trays per treatment).

When the seedlings reached the three-pair true-leaf stage, 15 seedlings from each treatment were randomly lifted and transplanted into a plastic container $(53 \mathrm{~cm}$ long, $33 \mathrm{~cm}$ wide, $19 \mathrm{~cm}$ high) filled with 1 sandy loam : 1 bark (by volume). For each container, $10 \mathrm{~g}$ of a granular fertilizer $(6 \mathrm{~N}-40 \mathrm{P}-6 \mathrm{~K})$ was mixed with the medium. Each of the four treatments was replicated four times.

Date of first flowering of each plant was recorded. At anthesis of the third flower, 15 plants per treatment were harvested. Cut-flower quality, as measured by number of leaves, leaf length and width, shoot length, stem diameter, cut-flower weight, and flower number, were evaluated.

A completely randomized design was used and data were analyzed by analysis of variance, using Duncan's new multiple range test at $P \leq 0.05$ for mean separation.

\section{Results and Discussion}

At 8 weeks after sowing, growth of leaves at the first and second node was remarkably promoted by the chitosan soil treatment mixture (Table 1), and leaves of the third node had expanded, whereas no leaves appeared in the other treatments. The seed treatment had no effect at 8 weeks. At 11 weeks after sowing, leaves of the fourth node had expanded only in the chitosan-treated soil mixture. At 8 and 11 weeks after sowing, fresh and dry weights of shoot and root were remarkably increased by soil treatment with chitosan. Seed treatment with lactic acid had some promotive effect, but chitosan did not.

Soil treatment with chitosan hastened flowering $\approx 15 \mathrm{~d}$, whereas treatment of seeds with lactic acid, with or without chitosan, hastened it only 2 to $4 \mathrm{~d}$ (Table 2). At flowering, plants grown in chitosan-treated soil had about two more leaves than did plants in other treatments. Leaf length and width at the fifth node of plants grown in soil treated with chitosan were greater than those of plants in the other treatments. Shoots were also longer by $\approx 15$ $\mathrm{cm}$, while stem diameter did not differ among the treatments. Thus, chitosan soil treatment

Table 1. Effects of lactic acid ( $0.25 \%)$ and chitosan ( $0.1 \%$ on seed or $1 \%$ in soil) on leaf length and width and dry weight of Eustoma grandiflorum (Raf.) Shinn. cv. Kairyou Wakamurasaki seedlings.

\begin{tabular}{|c|c|c|c|c|c|c|c|c|c|c|c|c|}
\hline \multirow{3}{*}{$\begin{array}{l}\text { Sampling time } \\
\text { (weeks after sowing) }\end{array}$} & \multirow{3}{*}{$\begin{array}{c}\text { Lactic } \\
\text { acid }\end{array}$} & \multirow[b]{3}{*}{ Chitosan } & \multicolumn{2}{|c|}{ 1st node $(\mathrm{mm})$} & \multicolumn{2}{|c|}{ 2nd node $(\mathrm{mm})$} & \multicolumn{2}{|c|}{ 3rd node $(\mathrm{mm})$} & \multicolumn{2}{|c|}{ 4th node $(\mathrm{mm})$} & \multirow{2}{*}{\multicolumn{2}{|c|}{ Dry weight $(\mathrm{mg})$}} \\
\hline & & & Leaf & Leaf & Leaf & Leaf & Leaf & Leaf & Leaf & Leaf & & \\
\hline & & & length & width & length & width & length & width & length & width & Shoot & Root \\
\hline \multirow[t]{3}{*}{8} & --- & --- & $6.9 \mathrm{a}^{2}$ & $4.3 \mathrm{a}$ & $3.0 \mathrm{a}$ & $1.8 \mathrm{a}$ & $--^{y}$ & --- & & & $1.6 \mathrm{a}$ & $0.8 \mathrm{a}$ \\
\hline & Seed & Seed & $7.5 \mathrm{~b}$ & $5.3 \mathrm{~b}$ & $3.0 \mathrm{a}$ & $1.8 \mathrm{a}$ & --- & --- & & & $2.2 \mathrm{a}$ & $1.5 \mathrm{~b}$ \\
\hline & --- & Soil & $14.2 \mathrm{c}$ & $9.7 \mathrm{c}$ & $18.8 \mathrm{~b}$ & $11.8 \mathrm{~b}$ & 5.8 & 3.0 & & & $14.7 \mathrm{~b}$ & $4.0 \mathrm{c}$ \\
\hline 11 & --- & --- & $8.3 \mathrm{a}$ & $5.3 \mathrm{a}$ & $8.7 \mathrm{a}$ & $5.2 \mathrm{a}$ & $5.1 \mathrm{a}$ & $2.7 \mathrm{a}$ & --- & --- & $5.0 \mathrm{a}$ & $1.9 \mathrm{a}$ \\
\hline
\end{tabular}

${ }^{2}$ Mean separation within columns and times by Duncan's new multiple range test, $P \leq 0.05$.

${ }^{y}$ Seedlings did not form third or fourth node. 


\section{Crop Production}

Table 2. Effects of lactic acid $(0.25 \%)$ and chitosan ( $0.1 \%$ on seed or $1 \%$ in soil) on first flowering date and cut-flower quality of Eustoma grandiflorum (Raf.) Shinn. cv. Kairyou Wakamurasaki.

\begin{tabular}{|c|c|c|c|c|c|c|c|c|c|}
\hline \multirow{2}{*}{$\begin{array}{l}\text { Lactic } \\
\text { acid }\end{array}$} & \multirow[b]{2}{*}{ Chitosan } & \multirow{2}{*}{$\begin{array}{c}\text { 1st flowering date } \\
\text { (Month/day) }\end{array}$} & \multirow{2}{*}{$\begin{array}{l}\text { No. node } \\
\text { (pair) }\end{array}$} & \multicolumn{2}{|c|}{ 5th node $(\mathrm{cm})$} & \multirow{2}{*}{$\begin{array}{l}\text { Shoot length } \\
(\mathrm{cm})\end{array}$} & \multirow{2}{*}{$\begin{array}{l}\text { Stem diam } \\
(\mathrm{mm})\end{array}$} & \multirow{2}{*}{$\begin{array}{l}\text { Cut-flower } \\
\text { weight }(\mathrm{g})\end{array}$} & \multirow{2}{*}{$\begin{array}{c}\text { No. } \\
\text { flowers }\end{array}$} \\
\hline & & & & Leaf length & Leaf width & & & & \\
\hline-- & --- & $8 / 2 c^{z}$ & $10.1 \mathrm{a}$ & $9.8 \mathrm{a}$ & $4.6 \mathrm{a}$ & $86.9 \mathrm{a}$ & $5.9 \mathrm{a}$ & $62.4 \mathrm{a}$ & $17.0 \mathrm{a}$ \\
\hline Seed & --- & $7 / 28 \mathrm{~b}$ & $10.2 \mathrm{a}$ & $9.0 \mathrm{a}$ & $4.4 \mathrm{a}$ & $87.6 \mathrm{a}$ & $6.0 \mathrm{a}$ & $60.6 \mathrm{a}$ & $18.3 \mathrm{ab}$ \\
\hline Seed & Seed & $7 / 26 b$ & $9.4 \mathrm{a}$ & $9.1 \mathrm{a}$ & $4.6 \mathrm{a}$ & $83.7 \mathrm{a}$ & $5.8 \mathrm{a}$ & $59.7 \mathrm{a}$ & $18.1 \mathrm{ab}$ \\
\hline--- & Soil & $7 / 17 \mathrm{a}$ & $11.9 \mathrm{~b}$ & $10.6 \mathrm{~b}$ & $4.9 \mathrm{~b}$ & $101.0 \mathrm{~b}$ & $6.4 \mathrm{a}$ & $69.8 \mathrm{~b}$ & $24.4 \mathrm{~b}$ \\
\hline
\end{tabular}

${ }^{2}$ Mean separation within columns by Duncan's new multiple range test, $P \leq 0.05$.

clearly promoted vegetative growth. Cutflower weight and flower number were greatest in plants grown in chitosan-treated soil. Thus, chitosan soil treatment remarkably promoted growth of Eustoma grandiflorum seedlings, hastened flowering time, and improved cut-flower quality as measured by leaf size, shoot length, and flower number.

Thus chitosan application may be useful for the culture of Eustoma in the spring when seedling growth is slow and cut-flower yield is reduced.

\section{Literature Cited}

Harbaugh, B.K. 1995. Flowering of Eustoma grandiflorum (Raf.) Shinn. cultivars influenced by photoperiod and temperature. HortScience 30:1375-1377.
Hirano, S. 1988. The activation of plant cells and their self-defence function against pathogens in connection with chitosan (in Japanese with English summary). Nippon Nogeikagaku kaishi 62:293-295.

Matsuo, T. and T. Shirasaki. 1990. Effect of rate of fertilization on the growth and nutrient uptake of Eustoma grandiflorum (in Japanese). J. Jpn. Soc. Hort. Sci. 59 (Suppl.1):584-585.

Shibuya, N., Y. Ito, and H. Kaku. 1996. Receptor for chitin-oligosaccharide in rice (in Japanese). Chem. Regulat. Plants. 31(2):125-133.

Tsugita, T., K. Takahashi, T. Muraoka, and H. Fukui. 1993. The application of chitin/chitosan for agriculture (in Japanese), p. 21-22. In: Proc. Spec. Session 7th Symp. on Chitin and Chitosan, Jpn. Soc. for Chitin and Chitosan, Fukui, Japan.

Tsukada, T., T. Kobayashi, and Y. Nagase. 1982. Studies on the physiological characters and cultivation of russell prairie gentian. II. Effect of temperature and photoperiod on the growth and flowering (in Japanese with English summary). Bul. Nagano Veg. and Ornam. Crops Expt. Sta. 2:77-88.

Tsukada, T., T. Mizutani, S. Aoyagi, and B. Nakamura. 1991a. Studies on the growth and flowering of Eustoma grandiflorum. 5. Effects of raising seedling condition on the growth and flowering (in Japanese). J. Jpn. Soc. Hort. Sci. 60 (Suppl.1):506-507.

Tsukada, T., T. Mizutani, S. Aoyagi, and A. Saito. 1991b. Studies on the growth and flowering of Eustoma grandiflorum. 6. Effects of environmental factors on the growth and flowering at the period of raising seedling and after planting chitosan (in Japanese). J. Jpn. Soc. Hort. Sci. 64 (Suppl.1):508-509.

Utsunomiya, N. and H. Kinai. 1994. Effect of chitosan-oligosaccharides soil conditioner on the growth of passionfruit (in Japanese). J. Jpn. Soc. Hort. Sci. 64 (Suppl.1):176-177. 